\title{
IAMJ
}

INTERNATIONAL

AYURVEDIC

MEDICAL JOURNAL

$\underline{\text { Review Article }}$

ISSN: 2320-5091

Impact Factor: 6.719

\section{ANATOMY DESCRIBED IN AYURVEDA AND MODERN SCIENCE: A REVIEW ARTICLE}

\author{
Ishan Malhotra*1, Sakshi ${ }^{2}$, Jannu Manohar ${ }^{3}$ \\ ${ }^{1}$ PG Scholar, Dept. of Rachana Sharir \\ ${ }^{2}$ Assistant Professor, Dept of Rachana Sharir \\ ${ }^{3}$ Professer, Dept. of Rachana Sharir \\ Sriganganagar College of Ayurvedic Science \& Hospital, Tantia University, Sriganganagar - 335001, India
}

Corresponding Author: docmalhotra88@gmail.com

https://doi.org/10.46607/iamj4109082021

(Published Online: August 2021)

Open Access

(C) International Ayurvedic Medical Journal, India 2021

Article Received: 30/07//2021 - Peer Reviewed: 11/08/2021 - Accepted for Publication: 12/08/2021

Check for updates

\begin{abstract}
Anatomy is broadly appreciated as being one of the cornerstones of medical education. If we go through the history of human anatomy, it seems that the anatomy of modern times is well recognized from the days of the renaissance that is from the $15^{\text {th }}$ century. Medical Science was one area where surprising advances had been made in ancient times in India. Specifically, these advances were in the areas of human dissection, embryology, plastic surgery, extraction of cataracts, description of Asthi, Sandhi, Peshi, Snayu, Marma And Pramana Sharira etc. These do not just claim. There is documentary evidence to prove the existence of these practices. Acharya Sushruta has paid great should start his surgical carrier unless he is well aware of human anatomy. Acharya Charaka also studied the anatomy of the human body and various organs. He also described the number of muscles joints etc., in the human body. The object of the present study is to trace out the most significant and valuable hidden treasures of anatomy practised in the past by Acharya and its review in Modern science.
\end{abstract}

Keywords: Asthi, Sandhi, Plastic surgery, Snayu Marma

\section{INTRODUCTION}

Anatomy is broadly appreciated as being one of the cornerstones of medical education. If we go through the history of human anatomy, it seems that the anatomy of modern times is well recognized from 
the days of the renaissance that is from the 15 th century. The foundation stone of modern anatomy is the work of Andreas Vesalius: De Fabrica Corporis Humani, published in 1543. Sushruta is considered as the father of surgery even today, but if we go through the Ayurveda text, the essentials of human anatomy are very precisely described by Sushruta, so he should also consider it as the father of human anatomy. Acharya Sushruta has paid great attention to the structural organization of the human body. This was emphasized to such an extent that no surgeon should start his surgical carrier unless he is aware of human anatomy. Acharya Charaka also studied the anatomy of the human body and various organs. He also described the numbers of muscles, joints etc. in the human body.

\section{AIM AND OBJECTIVE}

To explore and analyze the textbooks of Ayurveda to find the fundamentals of human anatomy and its relevance in Modern Science

\section{MATERIALS AND METHODS}

References related to the proposed title are collected from classical texts of Ayurveda especially Brihattrayi. Various publications, the internet, books related to modern anatomy, research papers related to the topic are collected.

\section{REVIEW OF AYURVEDIC LITERATURE}

In this context, some basic concepts are described to show that scientific knowledge of human anatomy was very well known to our Acharya. These are the following:

\section{Shadanga sharira (Concept of regional anatomy)}

Charaka and Sushruta have divided the human body into six following regions - two upper extremities, two lower extremities, head and neck and trunk. Acharya Vagbhatta has also said that the head, trunk, two arms and two legs are in brief the six Anga of the body.

\section{Asthi sharira (Concept of Osteology)}

Sushruta has described the importance of Asthi that how these are the major supporting framework of our body, and he also mentioned their types with their examples. He told that just as the tree remains firm on the ground by their inert wood; similarly, the body remains in erect position by the support of the Asthi inside it. Though the skin and muscles get destroyed after some time, Asthi does not get destroyed since these are the Sara (essence) of the body.

\section{Asthi prakara (Type of bones)}

These Asthi are of five kinds. These are as follows Kapala (flat), Rucaka, Taruna (cartilage), Valaya (curve) and Nalaka (tubular) Asthi. Out of these $\mathrm{Ka}$ pala asthi are found in the knee, pelvis, scapula, cheek, palate, temple, and head; Rucaka asthi are the teeth; Taruna asthi are found in the nose, ear, neck and eye orbit; Valaya asthi are found in the flanks, the back and the thorax and the rest of the Asthi are the Nalaka asthi.

\section{Asthi Sankhya (Number of bones)}

According to the followers of Vedas, there are three hundred and sixty Asthi in the body; but in the Shalya tantra, only three hundred Asthi are recognized. Out of these one hundred and twenty Asthi are found in the extremities, one hundred and seventeen in the pelvis, flank, back and the thorax and sixtythree in the region above the neck. In this way, a total of three hundred Asthi is completed.

\section{Sandhi sharira (Concept of syndesmology)}

The Sandhi are of two types- Chala (movable) and Achala (immovable). The movable joints are found in the extremities, mandible, and hip. All other joints should be considered immovable.

\section{Description of Peshi (Myology)}

Acharya Sushruta has described the Peshi in Sharira sthana - Peshi are thick or thin, big or minute, stout/thick or round/circular, short or long, fix/stable, hard or soft, smooth or rough; they cover the Sandhi, asthi, sira and Snayu, in their places naturally.

\section{Description of Snayu (Ligament)}

Sushruta has told that as a boat prepared by joining firmly many wooden planks can bear the weight of persons in the water, similarly all the Sandhi of the body bound by many Snayu can sustain body weight. Injury to Asthi, peshi, sira and Sandhi does not cause as much disability as an injury to the Snayu.

Pramana sharira (Concept of Anthropometry)

According to Sushruta- The measures have been described with one's own Angula (Fingers) as the 
yardstick. The male or female, possessing all these standard criteria will be having healthy and diseasefree life. Among them, those having medium proportions will have moderate life expectancy and wealth while one of inferior proportion is poor in both.

According to Charaka- The measurements of the body are described by the measures of individual Angula in terms of height, breadth, and length respectively. Thus, measurements of the body parts are discussed separately. The entire body measures eighty-four Angula in height and breadth. The persons having a normal measurement of the body will possess longevity, strength, immunity, happiness, supremacy, wealth, and other desired qualities. Those having bodies with less or more measurements have qualities contrary to these.

\section{Description of Marma (Vital points)}

There are one hundred and seven Marmas. These Marma are of five types. They are as follows: Mar$m a$ is in the Mamsa (muscles), Sira (vessels), Snayu (ligaments), Asthi (bones) and Sandhi (joints). These are classified into five groups as Sadhya pranahara (instantly fatal), Kalantara pranahara (fatal after a time), Vishalyaghna (fatal on the extraction of foreign body), Vaikalyakara (disabling) and Rujakara (painful). Nineteen are Sadhya pranahara, thirtythree is Kalantara pranahara, three are Vishalyagh$n a$, forty-four is Vaikalyakara and eight are $R u$ jakara marma.

The areas where Mamsa, sira, snayu, asthi and Sandhi meet are known as Marma, which by their virtue of nature are especially the sites of Prana (life). Therefore, an injury to any one of the Marma invariably produces characteristic features. Injury to $S a d h$ ya pranahara marma kills within a week. The Kalantara prnaahara marma kills within a fortnight or a month. Out of these, injury to the Kshipra marma may kill even earlier. The Vishalyaghna marma when traumatized, kill sometimes.

\section{Importance of Trimarma}

There are one hundred and seven Marmas located in the trunk and limbs of the body. The affliction of any one of these produces excruciating pain because of the specific association of consciousness in these parts. Amongst these Marmas, the ones located in the trunk are more important than the ones located in the limbs because these limbs are dependent upon the trunk. Amongst the Marmas in the trunk, the ones located in the Hrudaya, Basti and Sira are the most important because these organs constitute the very basic substratum of the body.

\section{DISCUSSION}

Shadanga sharira (Concept of regional anatomy)

Acharya Charaka, Sushruta and Vagbhatta all three Acharya divided the whole body into six regions. There are various ways by which the study of anatomy can be done. For study purposes, anatomy can be divided into two following subtypes-macroscopic or gross anatomy and microscopic anatomy. Regional anatomy is one of the important branches of macroscopic anatomy. Similar to Ayurveda, according to modern science the regional anatomy considers the organization of the body as major parts or segments: the main body consisting of the head, neck and trunk (subdivided into thorax, abdomen, back and pelvis/perineum) and paired upper limbs and lower limbs. Regional anatomy is the method of studying the body's structure by focusing on a specific part, area or region; examining the arrangement and relationships of the various systemic structures (muscles, nerves, arteries) within it; and then usually continuing to study adjacent regions in an ordered sequence. Regional anatomy also recognizes the body's organization by layers: skin, subcutaneous tissue and deep fascia covering the deeper structures like muscles, skeleton and cavities which contain viscera. In this way, we can say that the concept of regional anatomy was known at that time also.

\section{Asthi sharira (Concept of Osteology)}

Charaka had not given a detailed description of Asthi (bone). He only mentioned the total numbers of Asthi in the human body, but Sushruta had explained in detail. He considered the Asthi as the framework of the body which helps in maintaining proper posture, shape, and skilled movements. Acharya Sushruta also described that Asthi is the solid part of the body. Modern science states that the bone is composed of 
two types of substances-organic and inorganic. The organic connective tissue makes it tough and flexible while inorganic calcium salts make it hard and rigid. The bones provide a surface for the attachment of muscles, tendons, ligaments. These serve as levers for muscular actions. Bones from the main supporting framework of the body and are primarily designed for more effective production of movements by attached muscles. Acharya Sushruta has given precise description so we can say that he was very well acquainted with the Asthi.

\section{Asthi Sankhya}

Sushruta classified the bones based on their structure or shape as flat bones, small cubical bones, cartilages, curved bones, and tubular bones. Classification of this accuracy shows he was a keen observer. Enumeration i.e., Sankhya of human parts is as important as the knowledge of a particular organ as stated by Acharya Charaka. According to Chakrapani- the knowledge of enumerating the Avayava of the human body is important in clinical practice. According to modern anatomy, there are about 206 bones in the adult human skeleton. The early Indian anatomist, on the other hand, count either 360 (Atreya) or 300 (Sushruta) bones. This vast difference is principal because (besides including the teeth, nails, and cartilages) they counted prominent parts of bones, such is now known as 'processes' or 'protuberances'. This difference may be due to the basis of counting bones in modern and ancient science. Modern science includes only those structures as bones that contains the Haversian system while in ancient times the basis may be the hardness of the body part and they also counted that structures that decay very late after death.

\section{Types of Asthi}

As Sharira rachana described in Samhita is not pure anatomy but is physiological anatomy. So, every aspect described has more meaning and importance than as idle and straightforward in modern anatomy. The concept of Asthi prakaras is also one of them. Here if we see typically types of Asthi are not described just for anatomical or gross study but they are aptly described on basis of clinician worth. By using
Tarka and Pramana we can understand that the five types defined are just symbols for major division. These merely are not just types, but these are five ways of divisions of bones on a different basis as discussed below.

1. based on hardness or ossification (Tarunasthi) This division is on type of constituency or hardness in particularly.

2. On basis of surface area (Kapalasthi) - This is based on the surface area of bone. Kapala as described is flat or has more area than thickness. This type of Asthi covers or encloses a certain part or area of the body.

3. On basis of specific shape (Valayakara) - It is a ring-like or round bone. Here this is described in the context of ribs. These types of bones are for providing support as well as helping in inspiration and expiration i.e., providing elasticity. These also function as a protector for enclosed vital organs.

4. On basis of length and endpoints (Nalakasthi) Here Asthi has more length than breadth. Bones described here have head or broad end but narrow midbody i.e., shaft. The main functions of these are origin and insertion of muscles, whose movements like flexion, adduction etc help in performing different movements. Thus, these bones can be called functional in locomotion.

5. Next division is an interesting type as sense organ (Rucakasthi) - Acharya Sushruta have divided next variety especially on the power of teeth as Rucaka, i.e., one which can sense or know the taste of food during the chewing process. Sandhi Sharira (Concept of syndesmology)

In Ayurveda, sandhi is classified into two types- Chala (movable) and Achala (immovable). These movable joints further may be divided into two subtypes-

(1) Alpa Chala (slightly movable) - like Pratara, samudga sandhi.

(2) Bahu Chala (Freely movable) - like Kora, ulukhala sandhi.

This classification resembles similar to the modern classification of joints which is following:

1. Synarthrosis -an immovable joint.

2. Amphiarthrosis - a slightly movable joint. 
3. Disarthrosis - a freely movable joint.

\section{Description of Peshi (Myology)}

In Ayurveda, peshi are classified or named based on their size, shape, action and the feeling of touch like thick or thin, big or minute, short or long are based on size; stout/thick or round/circular is based on their structure; fix/stable or movable is based on their movement; hard or soft, smooth or rough area based on the perception of touch.

In modern science, the nomenclature of muscles is also based on the same features. These are the following:

1. Shape: Deltoid (triangular)

a) Quadratus (quadrangular)-quadratus femoris

b) Rhomboid (diamond shaped)-rhomboid major

c) Rectus (straight)-rectus abdominis.

2. Size: Major (big)-pectoralis major

a) Minor (small)-pectoralis minor

b) Longus (long)-adductor longus

c) Brevis (small)-palmaris brevis.

3. Structure: Half tendon, half musclesemitendinosus

4. Action or movement: Extensor, flexor, abductor, adductor

5. Position: Anterior (front)-tibialis anterior, posterior (back)-tibialis posterior

a) Supra (above)-supraspinatus,

b) Infra (below)-infraspinatus

6. Depth: Superficialis (superficial)-flexor digitorum superficialis

a) Profundus (deep)-flexor digitorum profundus

b) Externus (external)-external oblique

c) Internus- internal oblique

In this way, we can say that the basic concept for the study and classification of myology was given by the seers of Ayurveda.

\section{Description of Snayu (ligament)}

The description of the ligament is mentioned in classics as Snayu. Sushruta knew that all the joints of the body are bounded by ligaments. They give strength to joints. He also said that if any injury happens to Sna$y u$, it causes more disability than the injuries of bones, muscles etc. Ligaments are fibrous bands that connect the adjacent bones, forming integral parts of the joints. Ligaments are important agents in maintaining stability at the joint. If any injury happens to ligaments, there will be pain often sudden and severe, a loud pop or snap during injury, swelling, a feeling of looseness in the joint and inability to put weight on the point without pain. As with other soft tissue injuries, ligament healing consists of inflammation followed by repair and then remodelling. The inflammatory phase follows trauma to collagen fibres and lasts for 3-5 days, depending on the severity of the injury. The repair phase is mediated by blood clotting over the damaged tissue for 3-21 days after the injury. The remodelling phase follows the repair phase and can last for up to a year. Because the remodelling phase lasts for up to a year, there is a potential weakness in the ligament and a risk of re-injury. So here we can say that Sushruta was well known for the structure of Snayu and its injury.

\section{Pramana Sharira (Concept of Anthropometry)}

Significance of Angula pramana in Ayurveda

1. Pramana sharira can be described as the knowledge related to the body in the context of life- span, measurement of parts and sub-parts of the body.

2. The body has been described (in terms of measurement) with its fingers. The entire body is 84 Angula in vertical length and if the vertical height of the body is equal to the horizontal length in position when arms are abducted up to 90 degrees, then it is in Sama pramana.

3. The persons having a normal measurement of the body are endowed with longevity, strength, immunity, happiness, supremacy, wealth, and other qualities. Those having bodies with less or more measurements have qualities contrary to these.

4. The expert physician succeeds in his work if he proceeds after examining the lifespan particularly based on measurement of parts and sub-parts of the body.

\section{References of Angula in Samhitas:}

Role in various fields of Ayurveda

1. For describing the anatomy and location of structures in the body concerning one another. 
2. For describing the length of body organs especially in the context of Marma.

3. For describing surgical incisions sites, Siravedha sites and dimensions of surgical instruments.

4. For describing the features of medicinal or herbal plants.

5. For describing the Panchakarma procedure and instruments.

6. For describing ingredients in Bhaishajya Kalpana. Anthropometry is the measurements of the human body which provides scientific methods and techniques for taking various measurements and observations. The word 'Anthropos' means human and 'Metry' means measurement. It is the science that defines physical measures of a person's size, form and functional capacities. It is the systematic collection and correlation of measurements of the human body. Anthropometric measurements are used as a proxy measure for many purposes for the assessment of health status, physique, obesity, growth and development, nutritional status, economic development, human evolution, estimating skeletal frame size, sports, and physical strength. The measurements of different body parts which include the segmental lengths, bodily breadth, circumferences of trunks and limbs, skin and subcutaneous tissue fold thickness are used for designing instruments and equipment for human use. It deals with various measurements related to the human body such as pelvimetry, craniometry, osteometry, skinfold thickness, height, and weight measurements etc. Instruments used for measurements - Stadiometer, Anthropometer Rod, Head Height Needle, Spreading Calliper, Skinfold calliper, Palatometer, Goniometer, Tape, Croniophore, Mandibulometer. All this description of Pramana shows that the concept of Pramana was developed very early in the era of Ayurveda. In Ayurveda, the concept of Pramana is used widely in different branches like Panchakarma, dravya guna, bhaishajya kalpana, sharira rachana etc. in different ways. Modern science developed the concept of Pramana in the form of the new branch which is called anthropometry. The difference is that in Ayurveda the measurements were taken with help of Swa-angula.
There was no development of instruments to take a measurement, but modern science has developed so many instruments like vernier calliper, anthropometer rod and craniophore.

\section{Concept of Marma (Vital points)}

In ancient times the war was a common situation of the people, and the kings, clinicians and surgeons were especially engaged with the associations of the army of the kings, as being the custodians of the health of the warriors. Injuries inflicting because of the use of the various types of weapons on the battlefield i.e. sword, arrow, Gada etc. we're belonging to the cut, puncture or blunt injuries involving various types of the structures in the body like arteries, muscles, nerves, bones and the visceral organs in general and when in combination specifying Marma. Marma is the meeting point of five structures. Ayurveda described various superficially and deeply situated sites of the human body such as Sira, asthi, mamsa, snayu, sandhi which are called vital points of the body. These special sites make various points which are termed as Marma (vital points). Sushruta has referred to 107 anatomical points as Marmas in the human body. If any injury or damage happens to these vital points due to any reason, it may be very harmful. That may cause death or any deformity in the body. He presented all the Marmas particularly based on injury results. Acharya Charaka has mentioned the importance of Trimarma (Hrudaya, Basti and nabhi). It shows that he knew that these are important and delicate viscera of the body and if any injury happens to these organs that will lead to trivial diseases and deformity or even death. Therefore, knowledge of these Marma is very essential for physicians and surgeons. In day-to-day life, the knowledge of Marma is seen in the sports like cricket ex. wearing abdomen guards, thigh pads, leg pads, hand gloves, helmets etc to protect the vital points like Janu, indrabasti, gulpha etc. So, like these, the ages old Marma vijnana can be utilized and accepted as applied Anatomy. In Chinese medicine, the science of acupressure, the art of Kungfu is the outcome of our old art of Marma (vital points) and its therapy respectively. Kalari payattu (martial arts) is also practised in Kera- 
la which is equivalent to the Marma vijnana (the science of vital points). Similarly, acupuncture is found in Chinese medicine, the art of puncturing the vital points with fine needles to treat the specific disease.

\section{CONCLUSION}

After such explicit discussion, it can be concluded as follows, the concept of regional anatomy was given as Shadanga sharira in Ayurveda. Classification of bones based on shape, size and texture was given firstly in Samhita. The basis of classification and nomenclature of muscles in modern science is similar to the Ayurvedic description of Peshi. The elaborated description of Pramana sharira in the ancient literature show a well-established concept of anthropometry in the past era.

\section{REFERENCES}

1. Dr Ram Karan Sharma and Vaidya Bhagwan Dash; Charaka Samhita English translation; Sharira sthana, chapter 7, verse no.5, Chaukhambha Sanskrit series office, Varanasi, 1996.

2. Prof. K. R. Shrikantha Murthy; Sushruta Samhita English translation; Sharira sthana chapter 5, verse no. 3, Chaukhambha orientalia, Varanasi.

\section{Source of Support: Nil}

\section{Conflict of Interest: None Declared}

How to cite this URL: Ishan Malhotra et al: Anatomy Described In Ayurveda And Modern Science: A Review Article. International Ayurvedic Medical Journal \{online\} 2021 \{cited August 2021\} Available from: http://www.iamj.in/posts/images/upload/1861_1867.pdf 